\title{
Associative effect of monensin sodium to virginiamycin on the performance of beef steers in the initial feedlot phase
}

\section{Efeito associativo da monensina sódica à virginiamicina sobre o desempenho de novilhos de corte na fase inicial de confinamento}

\author{
Mikael Neumann ${ }^{1}$; Giovanna Bobato Pontarolo ${ }^{2 *}$; Fernando Braga Cristo ${ }^{2}$; Bruno \\ José Venancio ${ }^{3}$; Alana Dornelles Manchur ${ }^{4}$; Robson Kyoshi Ueno ${ }^{5}$; André Martins \\ de Souza ${ }^{6}$; Eduardo Mateus Moresco ${ }^{2}$; Cherlyson Czelusniak ${ }^{4}$
}

\section{Highlights:}

The combined use of monensin sodium and virginiamycin increased daily weight gain.

The apparent digestibility of the diet did not change by supplementation.

Ingestive behavior was not affected by combinations of additives and doses.

\begin{abstract}
The objective was to evaluate the associative effect of monensin sodium to virginiamycin on the performance, dry matter intake, apparent digestibility and ingestive behavior of steers in the initial feedlot phase. The experiment lasted for 30 days, divided into two experimental periods. Thirty-six Angus Nellore steers, non-castrated, with a mean age of 10 months and an average weight of $300 \mathrm{~kg}$, were divided into 18 pens. Animals were assigned to three treatments with six replications each, with the inclusion of the following additives: T1-monensin sodium, dose of $200 \mathrm{mg}$ day $^{-1}$; T2-monensin sodium, dose of $125 \mathrm{mg} \mathrm{day}^{-1}+$ virginiamycin, dose of $125 \mathrm{mg} \mathrm{day}^{-1}$; and T3-monensin sodium, dose of $200 \mathrm{mg}$ day $^{-1}+$ virginiamycin, dose of $125 \mathrm{mg} \mathrm{day}^{-1}$. All experimental procedures were previously submitted to the UNICENTRO Committee for Ethics in Animal Experimentation (CEUA), and were approved for execution (Official Letter 021/2019). The combination of monensin sodium with virginiamycin at a dose of $200 \mathrm{mg}+125 \mathrm{mg}$ animal day $\mathrm{y}^{-1}$ showed greater $(\mathrm{P}<0.05)$ average daily weight gain $(1.919 \mathrm{~kg}$ day $\left.^{-1}\right)$ and better feed conversion (4.27 kg DM kg of weight gain $\left.{ }^{-1}\right)$ compared to diets with monensin alone $\left(200 \mathrm{mg}^{2}\right.$ animal day $\left.{ }^{-1}\right)$ or monensin combined with virginiamycin $(125 \mathrm{mg}+125 \mathrm{mg}$ animal day $\left.{ }^{1}\right)$, even with no significant $(\mathrm{P}>0.05)$ difference in DM intake, with a mean value of $7.88 \mathrm{~kg}$ animal day1. Regardless of the isolated or combined supplementation of the additives, no significant differences were detected in the analysis of the feeder and feces scores, ingestive behavior, and rectal temperature or infrared thermography during the evaluation period. The combination of monensin sodium with virginiamycin at $200 \mathrm{mg}+125 \mathrm{mg}$ animal day ${ }^{-1}$ proved to be efficient in the initial feedlot period,
\end{abstract}

1 Prof., Pós-Graduação, Cursos de Agronomia e Ciências Veterinárias, Universidade Estadual Do Centro Oeste, UNICENTRO, Guarapuava, PR, Brasil. E-mail: neumann.mikael@hotmail.com

2 Discentes do Curso de Mestrado do Programa de Pós-Graduação em Ciências Veterinárias, UNICENTRO, Colaboradores do Núcleo de Produção Animal, NUPRAN, Guarapuava, PR, Brasil. E-mail: eduardomateusmoresco@gmail.com; fernandobragacristo@ gmail.com; giovannabpontarolo@hotmail.com

3 Me. em Ciências Veterinárias, Área de Saúde e Produção Animal Sustentável, UNICENTRO, Colaborador do NUPRAN, Guarapuava, PR, Brasil. E-mail: bru.ze.venancio@gmail.com

4 Estagiários do NUPRAN, Graduandos do Curso de Medicina Veterinária, UNICENTRO, Guarapuava, PR, Brasil. E-mail: alanamanchur@hotmail.com; cherlysonczelusniak@gmail.com

5 Dr., Cooperaliança Carnes Nobres, Guarapuava, PR, Brasil. E-mail: robsonueno@hotmail.com

6 Discente do Curso de Doutorado do Programa de Pós-Graduação em Ciência Animal, Universidade Estadual de Londrina, UEL, Colaborador do NUPRAN, Londrina, PR, Brasil. E-mail: andrems_92@hotmail.com

* Author for correspondence 
determined by the greater weight gain and better feed conversion observed in this study.

Key words: Bovine. Feedlot adaptation phase. Food additives. Performance enhancers.

\section{Resumo}

O objetivo foi avaliar o efeito associativo da monensina sódica à virginiamicina sobre o desempenho, consumo de matéria seca, digestibilidade aparente e comportamento ingestivo de novilhos na fase de inicial de confinamento. A duração do experimento foi de 30 dias, divididos em dois períodos experimentais de 15 dias cada. Utilizou-se de 36 novilhos inteiros $1 / 2$ sangue Angus Nelore, com idade média 10 meses e peso médio de $300 \mathrm{~kg}$, divididos em 18 baias. Os animais foram divididos em três tratamentos com seis repetições cada, com a associação dos seguintes aditivos inclusos as rações: $T_{1}$ monensina sódica, dose de $200 \mathrm{mg} \mathrm{dia}{ }^{-1} ; \mathrm{T}_{2}$ - monensina sódica, dose de $125 \mathrm{mg} \mathrm{dia}^{-1}+$ virginiamicina, dose de $125 \mathrm{mg} \mathrm{dia}^{-1}$; e $\mathrm{T}_{3}$ - monensina sódica, dose de $200 \mathrm{mg} \mathrm{dia}^{-1}+$ virginiamicina, dose de $125 \mathrm{mg}$ dia $^{-1}$. Todos os procedimentos experimentais foram previamente submetidos à apreciação do Comitê de Conduta Ética no Uso de Animais em Experimentação (CEUA) da UNICENTRO, tendo sido aprovados para execução (Ofício $\mathrm{n}^{\circ}$ 021/2019). A associação de monensina sódica com virginiamicina na dose de $200 \mathrm{mg}+125 \mathrm{mg}$ animal $\mathrm{dia}^{-1}$ apresentou maior $(\mathrm{P}<0,05)$ ganho de peso médio diário $\left(1,919 \mathrm{~kg} \mathrm{dia}^{-1}\right)$ e melhor conversão alimentar $\left(4,27 \mathrm{~kg}\right.$ de MS kg de ganho de peso $\left.{ }^{-1}\right)$ comparativamente as dietas com monensina isolada (200 mg animal dia $\left.{ }^{-1}\right)$ ou monensina associada a virginiamicina (125 mg $+125 \mathrm{mg}$ animal dia $\left.^{-1}\right)$, mesmo não tendo sido observada $(\mathrm{P}>0,05)$ diferença na ingestão de MS, apresentando valor médio de 7,88 $\mathrm{kg}$ animal dia ${ }^{-1}$. Independentemente da suplementação isolada ou associada dos aditivos, não encontrou-se estatisticamente diferenças na análise dos escores de comedouro e fezes, comportamento ingestivo e temperatura retal ou termografia infravermelha durante o período avaliativo. A associação de monensina sódica com virginiamicina na dose de $200 \mathrm{mg}+125 \mathrm{mg}$ animal dia ${ }^{-1}$ demonstrou ser eficiente no período inicial do confinamento, determinado pelo maior ganho de peso e melhor conversão alimentar verificados neste estudo.

Palavras-chave: Aditivos alimentares. Bovino. Fase de adaptação ao confinamento. Melhoradores de desempenho.

\section{Introduction}

Cattle ranching in Brazil has undergone intense changes with regard to the development of strategies that allow the intensification of the meat production chain. The use of confinement and supplementation with food additives are widespread techniques, however some factors, such as the range of possible additive combinations, open up an array of possibilities for their use at different times during the finishing period.

According to Marques, Cooke, Francisco and Bohnert (2012), the adaptation period of cattle deserves special attention from nutritionists, as these animals are currently challenged by the stress generated mainly by transportation, thus requiring nutritional practices aimed at favoring the animal performance and health This period represents about $20 \%$ of the total feedlot time (Brown \& Millen, 2009).

Among the additives most used in animal nutrition, are ionophores, which come from several strains of Streptomyces, and monensin sodium (MO) is the most common (Soares, Silva, Frazão, \& Silva, 2015).

The selectivity generated by the use of MO decreases the population of gram-positive bacteria, allowing an increase in ruminal propionate synthesis, resulting in a decrease in the proportion of acetate, without significantly affecting energy production (Beacom \& Mir, 1985). Another action of MO is related to the possibility of reducing ruminal protein degradation, varying according to the quality of the protein supplied, thus resulting in less loss through the synthesis of ammonia, consequently greater 
amount of protein of high biological value would reach the small intestine for absorption (Zanine, Oliveira, \& Santos, 2006).

This change in the rumen microbiome determines the improvement in cattle performance, as there are changes in the proportion of short chain fatty acids (SCFA), with an increase in the molar proportion of propionate and a reduction in butyrate and acetate (Vendramini et al., 2016). Other effects caused by the use of ionophores are increased energy retention, reduced dry matter intake, and increased daily weight gain and feed efficiency (Duffield, Merrill, \& Bagg, 2012).

Oliveira and Millen (2014) report that 99.2\% Brazilian feedlots use additives in their diets, and that approximately $93.9 \%$ use ionophore antibiotics. Therefore, it is necessary to define the combinations that may be convenient. Thus, a possibility of use that can act in synergy with ionophores is virginiamycin (VM).

$\mathrm{VM}$ is a non-ionophore antibiotic of the streptogramin class produced by a mutant strain of Streptomyces virginae (De Somer \& Van Duck, 1955). Its activity mainly affects gram-positive bacteria, both aerobic and anaerobic, however, it has no effect on most gram-negative bacteria due to the impermeability of the cell membrane (Cocito, 1979).

VM is composed of two chemical components: factor $\mathrm{M} \quad(\mathrm{C} 25 \mathrm{H} 35 \mathrm{~N} 3 \mathrm{O} 7)$ and factor $\mathrm{S}$ (C43H49N7O10) (Crooy \& De Neys, 1972), with antibacterial activity dependent on the synergy between its two components, as long as their combination follows the 4: 1 ratio (Vanderhaeghe \& Parmentier, 1960). After the entry of VM into grampositive cells, it irreversibly binds to a ribosomal subunit (50S subunit), inhibiting the formation of the peptide bond during bacterial protein synthesis (DiGiambattista, Chinali, \& Cocito, 1989), leading to disruption of cellular metabolic processes and consequent bacteriostasis and death.
As a background to the levels of supplementation of the additives tested here, the Food and Agriculture Organization of the United Nations (FAO, 2009) determines that the maximum recommended dose of $\mathrm{MO}$ aimed at efficiency in ruminal fermentation is $360 \mathrm{mg} \mathrm{day}^{-1}$ or for confined animals of $40 \mathrm{mg} \mathrm{kg}^{-1}$ in the ready feed, whereas for $\mathrm{VM}$, the maximum dose recommended by the Ministry of Agriculture, Livestock and Food Supply (MAPA) is $75 \mathrm{mg} \mathrm{VM}$ $100 \mathrm{~kg}^{-1}$.

The action of antimicrobials in the ruminant diet has led to several studies seeking to measure their effects on animal production, however little research has been conducted to assess the associative effect of ionophore and non-ionophore antibiotics, their different dosages and effects on animal performance in the adaptive period. Therefore, the goal of the study was to evaluate the associative effect of monensin sodium combined with virginiamycin on performance, dry matter intake, apparent digestibility and ingestive behavior of steers in the initial feedlot phase.

\section{Material and Methods}

The experiment was carried out at the Animal Production Nucleus (NUPRAN, Núcleo de Produção Animal), in the Graduate Program in Veterinary Sciences, area of Sustainable Animal Production and Health, Agricultural and Environmental Sciences Sector, State University of the Midwest (UNICENTRO), in the city of Guarapuava, State of Paraná.All experimental procedures were previously submitted to the UNICENTRO Committee for Ethics in Animal Experimentation (CEUA), and approved for execution (Official Letter 021/2019).

The dry matter intake, animal performance, apparent digestibility and ingestive behavior were evaluated in steers undergoing adaptation to feedlot and receiving the following additives included to feed: Treatment 1 - monensin sodium, $200 \mathrm{mg}^{-}$day $^{-}$ 1; Treatment 2 - monensin sodium, $125 \mathrm{mg}_{\text {day }^{-1}}$ 
+ virginiamycin, $125 \mathrm{mg} \mathrm{day}{ }^{-1}$; and Treatment 3 monensin sodium, $200 \mathrm{mg}$ day $^{-1}+$ virginiamycin, $125 \mathrm{mg}$ day $^{-1}$.

Thirty-six steers, $1 / 2$ Angus Nellore blood, noncastrated males, from the same herd, with initial average weight of $300 \mathrm{~kg}$ and average age of 10 months were housed in 18 feedlot pens, 2 animals per pen, semi-roofed, with $15 \mathrm{~m}^{2}$ area, with a concrete feeder and automatic metal water trough, regulated by a float.

The experiment lasted for 30 days, divided into two 15-day evaluation periods, which refers to the adaptation of animals to feedlot, diets and facilities.

Feed was supplied twice a day, at 06 h: 00 a.m. and 05 h:30 p.m. as a complete mixed ration (RTM). The diets consisted of corn silage at a constant ratio of $40 \%$ roughage and $60 \%$ concentrate, on a dry matter basis. The adjustment in the supply was carried out daily, considering leftovers of $5 \%$, on a diet dry matter basis. The additives were supplied on the complete mixed ration, previously weighed and mixed with $50 \mathrm{~g}$ ground concentrate, in order to guarantee their total ingestion.

The concentrate was prepared in the commercial feed factory of Cooperativa Agrária (Guarapuava, State of Paraná, Brazil), formulated based on soybean meal, corn, wheat meal, soybean husk, malt root, calcitic limestone, dicalcium phosphate, livestock urea, common salt, and mineral vitamin premix, presented in pellets. The guarantee levels of premix per $\mathrm{kg}$ concentrate are as follows: vitamin A: 16,000 IU; vitamin D3: 2,000 IU; vitamin E: 25 IU; S: 0.36 g; Mg: 0.74 g; Na: 3.6 g; Co: $0.52 \mathrm{mg}$; $\mathrm{Cu}: 22.01 \mathrm{mg}$; Fe: $18.00 \mathrm{mg}$; I: $1.07 \mathrm{mg}$; Mn: 72.80 $\mathrm{mg}$; Se: $0.64 \mathrm{mg}$; and Zn: $95.20 \mathrm{mg}$.

During the 30 days of adaptation to the feedlot, samples of corn silage and concentrate were taken to determine the chemical composition of the diet (Table 1). Samples were dried in a ventilated oven at $55^{\circ} \mathrm{C}$ to constant weight and sequentially ground in a Wiley mill with a $1 \mathrm{~mm}$ diameter sieve. Analysis of dry matter (DM), crude protein (PB), mineral matter (MM) and ether extract (EE) were performed according to Association of Official Analytical Chemists [AOAC] (1990). The content of neutral detergent fiber (NDF) was obtained according to the Van Soest method (1991) with thermostable $\alpha$-amylase, and acid detergent fiber (ADF) and lignin (LIG), according to Goering and Van Soest (1970). For the determination of the contents of $\mathrm{P}$ and $\mathrm{Ca}$, analyses were performed according to Tedesco, Gianello, Bissani, Bohnen and Volhweiss (1995). The coefficient of total digestible nutrients (TDN) was calculated according to Weiss, Conrad and Pierre (1992) and the concentration of non-fiber carbohydrates (NFC) was calculated by difference, according to the formula: $\mathrm{NFC}=100-(\mathrm{MM}+\mathrm{CP}+$ $\mathrm{EE}+\mathrm{NDF})$, as indicated by AOAC (1990).

The product used based on monensin sodium (MO) was Rumensin ${ }^{\circledR}$ 200, produced by the company Elanco Saúde Animal, registered at MAPA under number SP-59410 30002, which is classified as an animal performance enhancer, and the product based on virginiamycin (VM) used was Eskalin ${ }^{\circledR}(20$ $\mathrm{g} \mathrm{kg}^{-1}$ virginiamycin), registered at MAPA by the company Phibro Saúde Animal Internacional Ldta. under number SP-09492 30012, which is classified as a performance-enhancing additive composed of virginiamycin and $99 \%$ calcium carbonate.

Animals were weighed at the beginning, middle and at the end of the experiment, after solid fasting for 10 hours, to determine the average daily weight gain (ADG). The daily dry matter intake, expressed in $\mathrm{kg} \mathrm{day}^{-1}$ (DDMI) or expressed as a percentage of body weight (DMIP) was measured by means of the difference between the daily amount of food supplied and the amount of leftover food from the previous day. To determine feed conversion (FC), we calculated the ratio of the average daily dry matter intake and the average daily weight gain obtained in the evaluation period (DDMI $\left.\mathrm{ADG}^{-1}\right)$. 
Table 1

Chemical composition of ingredients used in animal feed and average values of the experimental diet, on a total dry matter basis

\begin{tabular}{lccc}
\hline Parameter & Corn silage & Concentrate & Experimental diet \\
\hline Dry matter, \% & 41.37 & 90.57 & 70.89 \\
Mineral matter, \% DM & 2.99 & 5.40 & 4.44 \\
Ether extract, \% DM & 2.96 & 3.45 & 3.25 \\
Crude protein, \% DM & 6.26 & 18.32 & 13.50 \\
Neutral detergent fiber, \% DM & 53.18 & 25.18 & 36.37 \\
Acid detergent fiber, \% DM & 28.42 & 10.03 & 17.39 \\
Lignin, \% DM & 6.73 & 2.45 & 4.16 \\
Non-fiber carbohydrates, \% DM & 34.61 & 47.66 & 42.44 \\
Total digestible nutrients, \% & 67.94 & 80.82 & 75.67 \\
Ca, \% & 0.14 & 1.67 & 0.91 \\
P, \% & 0.22 & 0.58 & 0.40 \\
\hline
\end{tabular}

DM: dry matter, Ca: calcium, P: phosphorus.

In the middle of the adaptation period of the steers to the feedlot, the total collection of feces from each experimental unit was performed for 48 consecutive hours, concomitantly with the behavioral assessment. The feces collected at the end of each 6-hour shift were weighed individually per experimental unit and $500 \mathrm{~g}$ were taken to be dried in a ventilated oven at $55^{\circ} \mathrm{C}$ to constant weight. This procedure allowed to determine the fecal dry matter content (FDM), and sequentially to estimate the total fecal output on a dry matter basis (FTS), expressed in $\mathrm{kg}$ day $^{-1}$ dry matter.

In order to obtain the apparent digestibility of dry matter (DMD), homogeneous samples of the diet and feces were taken for further analysis. The DMD, expressed in $\mathrm{g} \mathrm{kg}^{-1} \mathrm{DM}$, was calculated using the formula: Digestibility $\{1-[$ (nutrient ingested nutrient excreted $) \div$ nutrient ingested] $\}$ x 100 .

Ingestive behavior was analyzed in the middle of the experiment, during 48 consecutive hours of observation, starting at 12 noon on the first day and ending at 12 noon on the third day. The visualizations were made by four observers per shift, in a rotation system every 6 hours. The readings were taken at regular intervals of 3 minutes, in order to maintain the accuracy in the monitoring regarding the time spent in each activity. Ingestive behavior was represented by idle, rumination, water intake and food intake activities, expressed in hours day ${ }^{-1}$.

The observations were recorded in two different worksheets, one for assessing the time spent in each activity, and the other for recording the number of times that each activity was performed. This methodology allows the determination of the frequency of activities (feeding, drinking, urination and defecation), expressed in number of times per day. In the night observation, the environment was maintained with artificial lighting, and the animals were previously adapted for this.

During the 30 days of the experiment, feces of each pen were evaluated daily by means of visual observation scores. Feces were classified by scores, ranging from 1 to 6 , in which: $1=$ liquid feces, mushy; 2 = liquid feces, mushy, with small piles of up to $2.5 \mathrm{~cm} ; 3=$ intermediate feces with concentric ring and 3 to $4 \mathrm{~cm}$ pile; $4=$ pasty feces 
with concentric ring and pile of more than $5 \mathrm{~cm} ; 5=$ drier stools without concentric ring and pile greater than $5 \mathrm{~cm} ; 6=$ hardened or dried stools, based on the methodology adapted from Looper, Stokes, Waldner and Jordan (2001) and Ferreira et al. (2013).

In addition to the ranking of feces scores, we also visually evaluated daily the dietary leftovers in relation to the proportion of corn silage and concentrate, on a dry matter basis. The leftovers were ranked by scores, ranging from 1 to 6 , where 1 $=60 \%$ silage and $40 \%$ concentrate; $2=50 \%$ silage and $50 \%$ concentrate $3=40 \%$ silage and $60 \%$ concentrate; $4=30 \%$ silage and $70 \%$ concentrate; and $5=20 \%$ silage and $80 \%$ concentrate; $6=10 \%$ silage and $90 \%$ concentrate, on a dry matter basis.

Aiming to evaluate the influence of treatments on possible inflammatory conditions or clinical signs of diseases, the temperature of the left front limb (hull region) and the central superficial skin region of the rumen was measured twice a week, on pre-set days and times (02h00 p.m.) with FLUKE infrared camera, Ti100. At the end of each experimental period, at the time of weighing, the animals' rectal temperature was also measured with a Bioland digital thermometer.

Data obtained for each variable were tested for normality by the "Shapiro-Wilk" test (PROC UNIVARIATE) and for homogeneity by the "Bartlett" test (PROC GLM). Subsequently, the results obtained were tested by analysis of variance, and subsequently means were compared by Tukey's test at 5\% significance, through the GLM procedure of SAS (Statistical Analysis System Institute [SAS
Institute], 1993). The experiment was a $3 \times 2$ factorial randomized block design, with three combinations of additives and two evaluation periods, with six repetitions, where each repetition (block) was represented by a pen with two animals each. The following statistical model was used: $Y_{i j k}=\mu+S_{i}$ $+\mathrm{P}_{\mathrm{j}}+\mathrm{B}_{\mathrm{k}}+(\mathrm{S} * \mathrm{P})_{\mathrm{ij}}+\mathrm{E}_{\mathrm{ijk}}$; Where: $\mathrm{Y}_{\mathrm{ijk}}=$ dependent variable; $\mu=$ overall mean of all observations; $S_{i}$ = Effect of additive "i", where $1=$ control diet with monensin sodium, dose of $200 \mathrm{mg}^{\text {day }}{ }^{-1}, 2=$ diet with monensin sodium, dose of $125 \mathrm{mg}^{-}$day $^{-}$ ${ }^{1}+$ virginiamycin, dose of $125 \mathrm{mg} \mathrm{day}^{-1}$, and $3=$ diet with monensin sodium, dose of $200 \mathrm{mg}$ day $^{-1}+$ virginiamycin, dose of $125 \mathrm{mg} \mathrm{day}^{-1} ; \mathrm{P}_{\mathrm{j}}=$ Effect of the feedlot period of order " $\mathrm{j}$ ", with 1 = first period and 2 second period; $B_{k}=$ Effect of the block of order " $k$ ", where $1=$ first, $2=$ second, $3=$ third, $4=$ fourth, $5=$ fifth and $6=\operatorname{sixth} ;(\mathrm{S} * \mathrm{P})_{\mathrm{ij}}=$ Effect of the interaction between additive dose and feedlot period of order “ij” and $\mathrm{E}_{\mathrm{ij}}=$ Residual random effect.

\section{Results and Discussion}

Based on the summary of the analysis of variance (Table 2), there was no interaction $(\mathrm{P}>0.05)$ between the combination of additives and the feedlot period assessed, for the following parameters: Average daily weight gain (ADG), dry matter intake (DMI), expressed in $\mathrm{kg}$ day $^{-1}$ (DDMI) or per $100 \mathrm{~kg}$ body weight (DMIP), feed conversion (CA), feeder score (FdS) and feces score (FS) and for temperatures of the left front limb (TMAE), central superficial skin region of the rumen (TCR) and of the rectum (TR). 


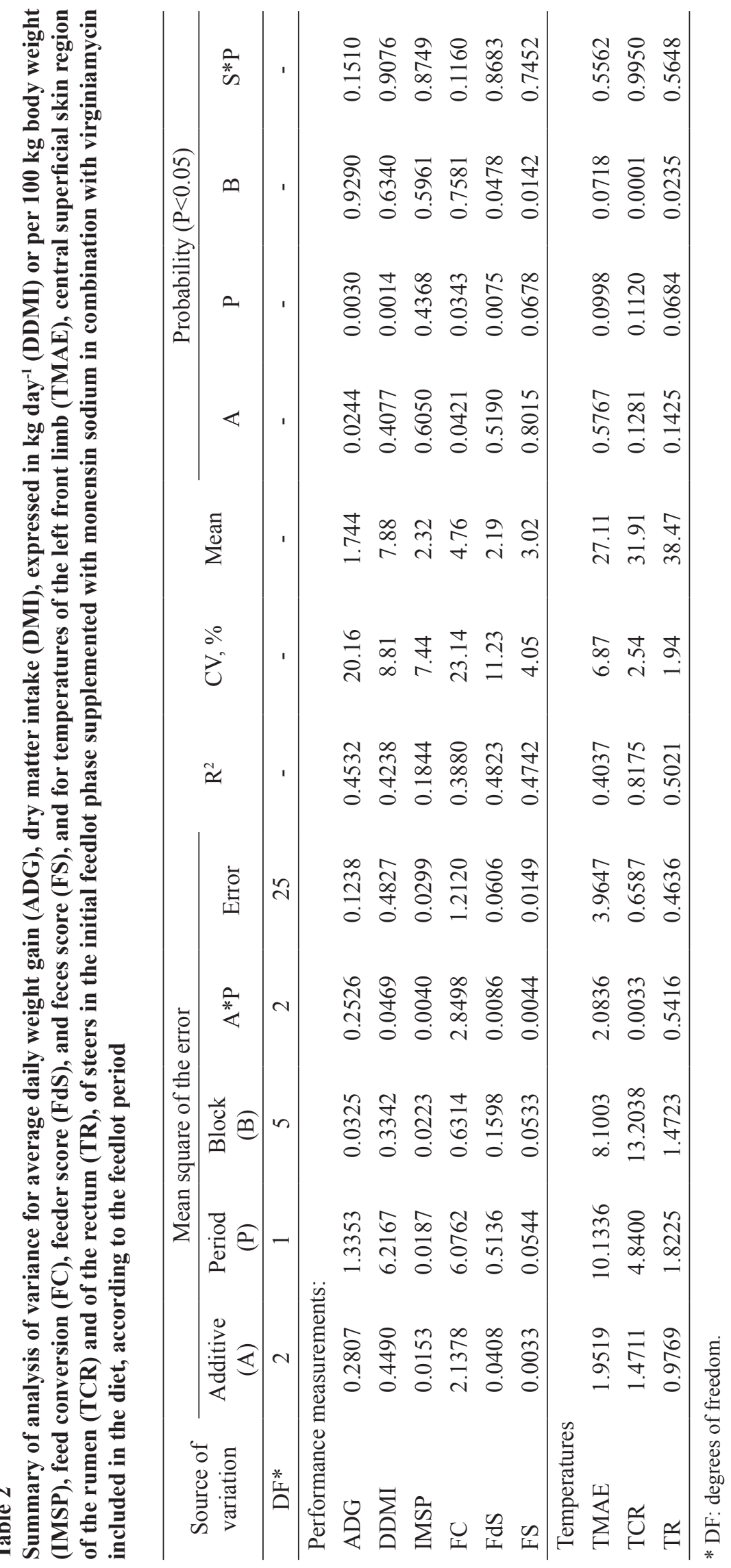


The combination $\mathrm{MO}$ in the dose of $200 \mathrm{mg}$ + VM $125 \mathrm{mg}$ animal day ${ }^{-1}$ provided greater $(\mathrm{P}$ $<0.05)$ average daily weight gain $\left(1.919 \mathrm{~kg} \mathrm{day}^{-1}\right)$ and better feed conversion (4.27 kg DM kg weight gain $^{-1}$ ) compared to diets with MO alone at the dose of $200 \mathrm{mg}$ animal day ${ }^{-1}\left(1.636 \mathrm{~kg} \mathrm{day}^{-1}\right.$ and $5.06 \mathrm{~kg}$ DM kg weight gain ${ }^{-1}$ ) or MO at the dose of $125 \mathrm{mg}$ animal day ${ }^{-1}$ combined with $\mathrm{VM}$ at a dose of $125 \mathrm{mg}$ animal day ${ }^{-1}\left(1.678 \mathrm{~kg} \mathrm{day}^{-1}\right.$ and $\left.4.94 \mathrm{~kg} \mathrm{DM} \mathrm{kg} \mathrm{weight} \mathrm{gain}{ }^{-1}\right)$. Regarding the mean values of dry matter intake, these remained constant $(\mathrm{P}>0.05)$ in the different treatments, regardless of the supplementation of additives (Table 3).

In the general mean, there was a positive highlight in the first 15 days of feedlot for the experimental group that received MO combined with VM (200 $\mathrm{mg}+125 \mathrm{mg}$ animal day ${ }^{-1}$ ) for determining greater $(\mathrm{P}<0.05)$ average daily weight gain and better feed conversion compared to diets with MO alone (200 mg animal day $\left.{ }^{-1}\right)$ or OM combined with VM (125 $\mathrm{mg}+125 \mathrm{mg}$ animal day $\left.{ }^{-1}\right)$. In turn, 15 days after the beginning of the feedlot, the parameters related to the animal performance and dry matter intake were similar $(\mathrm{P}>0.05)$ between the different treatments, no longer observing advantages of the combination of MO with VM in the dose of $200 \mathrm{mg}+125 \mathrm{mg}$ animal day ${ }^{-1}$.

Guan, Wittenberg, Ominski and Krause (2006) found that alternating supplementation of MO and lasalocide, and also the use of MO alone did not alter the ADG ( 0.90 and $\left.0.89 \mathrm{~kg} \mathrm{day}^{-1}\right)$ and the DMI of one-year-old steers receiving a low concentrate diet. The same authors investigated supplementation with ionophores in a diet with a proportion of $31 \%$ roughage and $69 \%$ concentrate and found better results in FC for both additives, with $7.23 \mathrm{~kg}$ DM $\mathrm{kg}$ weight gain ${ }^{-1}$ for the group receiving MO and $7.11 \mathrm{~kg} \mathrm{DM} \mathrm{kg}$ weight gain ${ }^{-1}$ for the group receiving the combination of $\mathrm{MO}$ and lasalocide. These data corroborate the present study regarding the improvement of FC when MO was combined with another additive, with values of $4.27 \mathrm{~kg}$ DM $\mathrm{kg}$ weight gain $^{-1}$ found for the combination of MO with VM $\left(200 \mathrm{mg}+125 \mathrm{mg}\right.$ animal day $\left.{ }^{-1}\right)$ and $5.06 \mathrm{~kg}$ DM kg weight gain ${ }^{-1}$ for MO alone (200 mg animal day $^{-1}$ ) in the present study.

\section{Table 3}

Average daily weight gain, daily dry matter intake and feed conversion of steers in the initial feedlot phase supplemented with monensin sodium combined with virginiamycin included in the diet, according to the feedlot period

\begin{tabular}{|c|c|c|c|}
\hline \multirow[b]{2}{*}{ Experimental diet } & \multicolumn{2}{|c|}{ Phase of adaptation to the feedlot } & \multirow[b]{2}{*}{ Mean } \\
\hline & $\begin{array}{l}\text { 1st period } \\
1-15 \text { days }\end{array}$ & $\begin{array}{l}\text { 2nd period } \\
16-30 \text { days }\end{array}$ & \\
\hline & \multicolumn{3}{|c|}{ Average daily weight gain, $\mathrm{kg}$ animal day ${ }^{-1}$} \\
\hline MO, $200 \mathrm{mg}$ day $^{-1}$ & 1.361 & 1.911 & $1.636 \mathrm{~B}$ \\
\hline MO, $125 \mathrm{mg} \mathrm{day}^{-1}+\mathrm{VM}, 125 \mathrm{mg}$ day $^{-1}$ & 1.400 & 1.956 & $1.678 \mathrm{~B}$ \\
\hline MO, $200 \mathrm{mg}$ day $^{-1}+\mathrm{VM}, 125 \mathrm{mg}$ day $^{-1}$ & 1.894 & 1.944 & $1.919 \mathrm{~A}$ \\
\hline \multirow[t]{2}{*}{ Mean } & $1.552 \mathrm{~b}$ & $1.937 \mathrm{a}$ & \\
\hline & \multicolumn{3}{|c|}{ Dry matter intake, $\mathrm{kg}$ animal day ${ }^{-1}$} \\
\hline MO, $200 \mathrm{mg} \mathrm{day}^{-1}$ & 7.49 & 8.40 & $7.95 \mathrm{~A}$ \\
\hline MO, $125 \mathrm{mg} \mathrm{day}^{-1}+\mathrm{VM}, 125 \mathrm{mg} \mathrm{day}^{-1}$ & 7.32 & 8.01 & $7.66 \mathrm{~A}$ \\
\hline MO, $200 \mathrm{mg}$ day $^{-1}+$ VM, $125 \mathrm{mg} \mathrm{day}^{-1}$ & 7.58 & 8.48 & $8.03 \mathrm{~A}$ \\
\hline Mean & $7.46 \mathrm{~b}$ & $8.30 \mathrm{a}$ & \\
\hline
\end{tabular}




\begin{tabular}{|c|c|c|c|}
\hline & \multicolumn{3}{|c|}{ Dry matter intake per $100 \mathrm{~kg}$ body weight, $\%$} \\
\hline $\mathrm{MO}, 200 \mathrm{mg}$ day $^{-1}$ & 2.32 & 2.39 & $2.35 \mathrm{~A}$ \\
\hline MO, 125 mg day ${ }^{-1}+\mathrm{VM}, 125 \mathrm{mg} \mathrm{day}^{-1}$ & 2.28 & 2.29 & $2.29 \mathrm{~A}$ \\
\hline MO, 200 mg day ${ }^{-1}+$ VM, 125 mg day ${ }^{-1}$ & 2.31 & 2.37 & $2.34 \mathrm{~A}$ \\
\hline \multirow[t]{2}{*}{ Mean } & $2.30 \mathrm{a}$ & $2.35 \mathrm{a}$ & \\
\hline & \multicolumn{3}{|c|}{ Feed conversion (Dry matter intake Weight gain ${ }^{-1}$ ) } \\
\hline MO, $200 \mathrm{mg}_{\text {day }}{ }^{-1}$ & 5.60 & 4.51 & $5.06 \mathrm{~B}$ \\
\hline $\mathrm{MO}, 125 \mathrm{mg}$ day $^{-1}+\mathrm{VM}, 125 \mathrm{mg} \mathrm{day}^{-1}$ & 5.75 & 4.12 & $4.94 \mathrm{~B}$ \\
\hline MO, 200 mg day ${ }^{-1}+\mathrm{VM}, 125 \mathrm{mg}$ day $^{-1}$ & 4.14 & 4.40 & $4.27 \mathrm{~A}$ \\
\hline Mean & $5.17 \mathrm{~b}$ & $4.35 \mathrm{a}$ & \\
\hline
\end{tabular}

Mean values followed by different lowercase letters, in the same row, are significantly different by F-Test at 5\%.

Mean values followed by different capital letters, in the same column, are significantly different by Tukey's test at $5 \%$.

MO: monensin sodium, VM: virginiamycin.

Although MO is the most researched ionophore, salinomycin in studies that evaluate performance parameters has generated results close to $\mathrm{MO}$ (Gibb, Moustafa, Wiedmeier, \& McAllister, 2001). In an experiment using Nellore steers, supplemented with $13 \mathrm{mg} \mathrm{kg}^{-1}$ salinomycin combined or not with VM $\left(15 \mathrm{mg} \mathrm{kg}^{-1}\right)$ fed a diet composed of $73 \%$ concentrate, Nuñez et al. (2013) reported a decline in the DMI of the animals that received the combination of additives $\left(6.85 \mathrm{~kg}\right.$ day $\left.^{-1}\right)$, differently from what was observed in the present study. The ADG found by the same author showed no synergy between the additives, remaining at $1.240 \mathrm{~kg} \mathrm{day}^{-1}$.

Heker et al. (2018) examined the performance of confined steers receiving MO combined with VM and/or essential oils and found that the ADG for treatment with $\mathrm{MO}$ was $1,329 \mathrm{~kg}$ day $^{-1}$ versus 1,559 $\mathrm{kg} \mathrm{day}^{-1}$ in the combination of MO and VM, these data are in line with data of the present experiment with $1,636 \mathrm{~kg}$ day $^{-1}$ versus $1,799 \mathrm{~kg}$ day $^{-1}$ of the average of the treatments receiving different doses of MO and VM, that is, the combination of these provided greater daily gain regardless of the dosage provided.

According to Bergen and Bates (1984), ionophores are capable of reducing the synthesis of lactic acid, thus avoiding metabolic disorders like acidosis. The remarkable role of VM in modifying the microbial population favors the stabilization of rumen $\mathrm{pH}$ (Nuñez et al., 2013). Thus, it is inferred that the improvement in ruminal health, especially important in diets containing a higher concentrate content, favored the increase in ADG in animals that received the combination of MO and VM (200 $\mathrm{mg}+125 \mathrm{mg}$ animal day $\left.^{-1}\right)$.

Besides that, according to Sitta (2011), VM is responsible for reducing the synthesis of methane, decreasing energy losses, a fact that adds up to the better performance of animals whose treatments had VM.

Assessing the supply of VM and salinomycin to grazing animals, Ferreira (2013) found an increase of 118 grams animal $^{-1}$ in the ADG for the group receiving $\mathrm{VM}$, in relation to the control treatment ( $0.583 \mathrm{~kg}$ day $^{-1}$ versus $\left.0.465 \mathrm{~kg} \mathrm{day}^{-1}\right)$, and 52 grams animal day ${ }^{-1}$ in supplementation with salinomycin $\left(0.583 \mathrm{~kg}\right.$ day $^{-1}$ versus $0.531 \mathrm{~kg}$ day $\left.^{-1}\right)$.

Silva, Almeida, Schwahofer, Leme and Lanna (2004) also did not observe an improvement in the ADG of animals receiving VM or salinomycin alone, but when supplied in combination, there was an increase in ADG, as observed in this study in the group that received the combination of $\mathrm{MO}$ with VM (200 mg + $125 \mathrm{mg}$ animal day $\left.{ }^{-1}\right)$. 
Regarding the mean values of dry matter intake (DMI), these remained constant $(\mathrm{P}>0.05)$ in the different treatments evaluated, regardless of additive supplementation.

Although Tedeschi, Fox and Tylutki (2003) cite that it is common the lower intake by animals that received MO in the diet, the moderate level of inclusion tested in the present study may have been responsible for not observing this reduction in DMI, despite having provided increased ADG in combination with VM (200 mg $+125 \mathrm{mg}$ animal day $\left.^{-1}\right)$.

Pereira et al. (2015) found a decrease in the mean values of DMI in animals receiving MO in different dosages compared to the control group (10.66 kg animal day ${ }^{-1}$ against $11.23 \mathrm{~kg}$ animal day ${ }^{-}$ $\left.{ }^{1}\right)$. These results differ from the present study, where there was no difference $(\mathrm{P}>0.05)$ for DMI between treatments, including the combinations of $\mathrm{MO}$ with VM. The same result was reported by Rogers et al. (1995), where there was an increase in animal performance without affecting the dry matter intake.

Heker et al. (2018), when evaluating the DMI of steers confined and supplemented with MO alone or MO combined with VM, also did not obtain any difference between treatments. Squizatti (2019) evaluated 5 cannulated cattle, adapted for 14 days and supplemented with $\mathrm{MO}$ alone $\left(30 \mathrm{mg} \mathrm{kg}^{-1}\right)$ or $\mathrm{MO}+\mathrm{VM}\left(30 \mathrm{mg} \mathrm{kg}^{-1}+25 \mathrm{mg} \mathrm{kg}^{-1}\right)$ and found no differences in DMI corroborating the present experiment.

In the general mean, no effects $(\mathrm{P}>0.05)$ from the use of MO were detected, alone or when combined with VM in relation to leftover in feeders and feces scores in the initial phase of confined steers (Table 4).

In the evaluation between feedlot periods, regardless of the use of additives, a lower feeder score $(\mathrm{P}<0.05)$ was found in the initial period, compared to the second period (2.1 versus 2.3 ), that is, the animals tended to ingest a little more of the bulky fraction of the diet initially, since the supply followed the 60:40 ratio, but without differences $(\mathrm{P}>0.05)$ between the different treatments. As for the feces scores, these remained stable $(\mathrm{P}>0.05)$ in the two evaluation periods and during the adaptation of steers to the feedlot.

\section{Table 4}

Average fecal output, on the natural and dry matter basis in $\mathrm{kg} \mathrm{day}^{-1}$, apparent digestibility of feed and ingestive behavior regarding aspects of feeder score and feces score of steers in the initial feedlot phase supplemented with monensin sodium combined with virginiamycin included in the diet

\begin{tabular}{lccc}
\hline Experimental diet & $\begin{array}{c}\text { Fecal output } \\
\text { kg MN day }^{-1}\end{array}$ & $\begin{array}{c}\text { Fecal output } \\
\mathrm{kg} \mathrm{DM} \mathrm{day}^{-1}\end{array}$ & $\begin{array}{c}\text { DM digestibility } \\
\%\end{array}$ \\
\hline MO, $200 \mathrm{mg} \mathrm{day}^{-1}$ & $13.75 \mathrm{~A}$ & $2.56 \mathrm{~A}$ & $66.52 \mathrm{~A}$ \\
$\mathrm{MO}, 125 \mathrm{mg} \mathrm{day}^{-1}+\mathrm{VM}, 125 \mathrm{mg} \mathrm{day}^{-1}$ & $13.49 \mathrm{~A}$ & $2.51 \mathrm{~A}$ & $66.69 \mathrm{~A}$ \\
$\mathrm{MO}, 200 \mathrm{mg} \mathrm{day}^{-1}+\mathrm{VM}, 125 \mathrm{mg} \mathrm{day}^{-1}$ & $14.94 \mathrm{~A}$ & $2.80 \mathrm{~A}$ & $65.77 \mathrm{~A}$ \\
Mean & 14.06 & 2.62 & 66.33 \\
Probability & 0.4242 & 0.1171 & 0.1522 \\
$\mathrm{CV}, \%$ & 13.84 & 4.25 & 3.24 \\
\hline & \multicolumn{3}{c}{ Phase of adaptation to the feedlot } \\
Experimental diet & 1st period & 2nd period & Mean \\
\hline
\end{tabular}




\begin{tabular}{lccc}
\hline & \multicolumn{3}{c}{ Daily feeder score } \\
\cline { 2 - 4 } MO, $200 \mathrm{mg} \mathrm{day}^{-1}$ & 2.1 & 2.3 & $2.2 \mathrm{~A}$ \\
MO, $125 \mathrm{mg} \mathrm{day}^{-1}+\mathrm{VM}, 125 \mathrm{mg} \mathrm{day}^{-1}$ & 2.0 & 2.2 & $2.1 \mathrm{~A}$ \\
MO, $200 \mathrm{mg} \mathrm{day}^{-1}+\mathrm{VM}, 125 \mathrm{mg} \mathrm{day}^{-1}$ & 2.1 & 2.3 & $2.2 \mathrm{~A}$ \\
Mean & $2.1 \mathrm{~b}$ & $2.3 \mathrm{a}$ & \\
\hline & & Daily feces score \\
MO, $200 \mathrm{mg} \mathrm{day}^{-1}$ & 3.0 & 2.9 & $3.0 \mathrm{~A}$ \\
MO, $125 \mathrm{mg} \mathrm{day}^{-1}+\mathrm{VM}, 125 \mathrm{mg} \mathrm{day}^{-1}$ & 3.0 & 3.0 & $3.0 \mathrm{~A}$ \\
MO, $200 \mathrm{mg} \mathrm{day}^{-1}+\mathrm{VM}, 125 \mathrm{mg} \mathrm{day}^{-1}$ & 3.1 & 3.0 & $3.0 \mathrm{~A}$ \\
Mean & $3.0 \mathrm{a}$ & $3.0 \mathrm{a}$ & \\
\hline
\end{tabular}

Mean values followed by different capital letters, in the same column, are significantly different by Tukey's test at $5 \%$. MO: monensin sodium, VM: virginiamycin, MN: natural matter, DM: dry matter.

There was no variation $(\mathrm{P}>0.05)$ for the parameters related to the average fecal output, on the natural and dry matter basis in $\mathrm{kg} \mathrm{day}^{-1}$ and apparent digestibility of the feed, with mean values of $14.06 \mathrm{~kg} \mathrm{MN}_{\text {day }}{ }^{-1}, 2.62 \mathrm{~kg} \mathrm{DM}$ day $^{-1}$ and $66.33 \%$, respectively. These data corroborate Fonseca (2012), who found no statistical difference for apparent digestibility of the diet in a 50:50 proportion, in steers supplemented with a combination of MO and VM.

Zeoula et al. (2008) analyzed the supplementation with $\mathrm{MO}$ in diets with $50 \%$ concentrate in the diet, and obtained a value of $61 \%$ for in vitro digestibility of DM. In an experiment carried out by Fereli et al. (2010), in a diet with $70 \%$ concentrate and 30\% roughage, and supplementation with $200 \mathrm{mg}$ day $^{-1}$ $\mathrm{MO}$, obtained $64.17 \%$ apparent digestibility of the diet, these results suggest a better action of MO in diets with higher content of concentrate

There were no $(\mathrm{P}>0.05)$ effects of using MO alone or in combination with VM regarding ingestive behavior (expressed in hours day ${ }^{-1}$ or number of times day ${ }^{-1}$ ) (Table 5).

As for the rumination behavior and time, an experiment carried out by Sitta (2011) showed no difference with the inclusion of MO and/or MO combined with VM. According to Heker et al. (2018), these results can be explained by the same physical characteristic of the feed, being different only the supplementation offered to the animals. Pereira et al. (2015) evaluated the diet with inclusion of MO in different dosages, and also observed no difference in the number of trips to the feeder, with an average value of 15.53 times day ${ }^{-1}$. 


\section{Table 5}

Ingestive behavior (hours day ${ }^{-1}$ and number of times day ${ }^{-1}$ ) of steers in the initial feedlot phase supplemented with monensin sodium combined with virginiamycin included in the diet

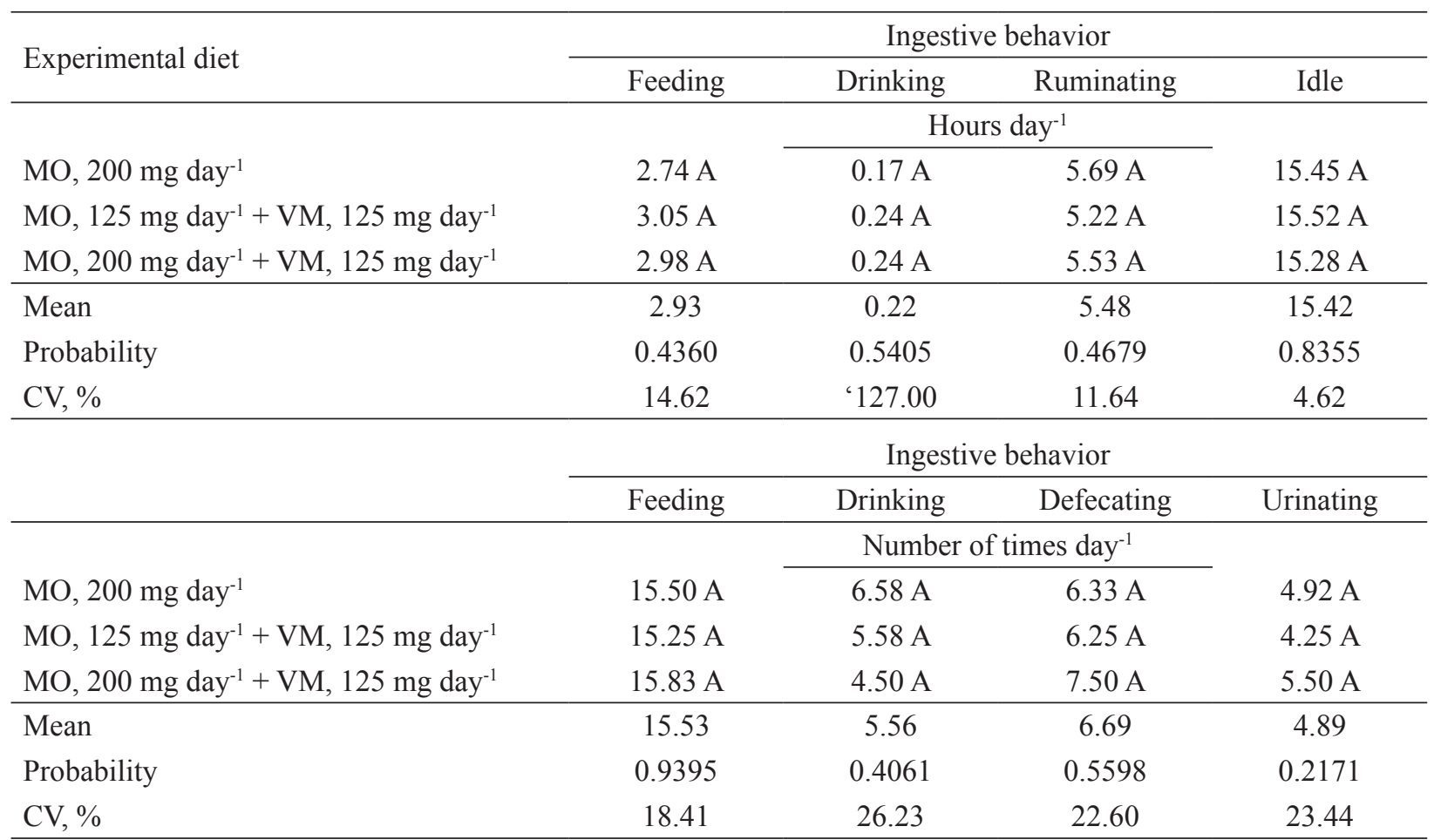

Mean values followed by different capital letters, in the same column, are significantly different by Tukey's test at $5 \%$.

MO: monensin sodium, VM: virginiamycin.

In the present experiment, there was no $(\mathrm{P}>0.05)$ effect of the use of MO alone or in combination with VM regarding variations in the temperature of the left front limb, rumen and of the rectum of steers during the phase of adaptation to feedlot, as well, temperature values did not change $(\mathrm{P}>0.05)$ during the evaluation period (Table 6). 
Table 6

Temperature of the left front limb, central superficial skin region of the rumen and rectum of steers in the initial feedlot phase supplemented with monensin sodium in combination with virginiamycin included in the diet, according to the feedlot period

\begin{tabular}{|c|c|c|c|}
\hline \multirow[b]{2}{*}{ Experimental diet } & \multicolumn{2}{|c|}{ Phase of adaptation to the feedlot } & \multirow[b]{2}{*}{ Mean } \\
\hline & $\begin{array}{l}\text { 1st period } \\
1-15 \text { days }\end{array}$ & $\begin{array}{l}\text { 2nd period } \\
16-30 \text { days }\end{array}$ & \\
\hline & \multicolumn{3}{|c|}{ Left front limb, ${ }^{\circ} \mathrm{C}$} \\
\hline MO, $200 \mathrm{mg}_{\text {day }}{ }^{-1}$ & 28.21 & 26.71 & $27.46 \mathrm{~A}$ \\
\hline MO, $125 \mathrm{mg}$ day $^{-1}+\mathrm{VM}, 125 \mathrm{mg}$ day $^{-1}$ & 26.70 & 26.63 & $26.67 \mathrm{~A}$ \\
\hline MO, $200 \mathrm{mg}$ day $^{-1}+\mathrm{VM}, 125 \mathrm{mg}$ day $^{-1}$ & 28.01 & 26.44 & $27.23 \mathrm{~A}$ \\
\hline \multirow[t]{2}{*}{ Mean } & $27.64 \mathrm{a}$ & $26.59 \mathrm{a}$ & \\
\hline & \multicolumn{3}{|c|}{ Rumen, ${ }^{\circ} \mathrm{C}$} \\
\hline MO, 200 mg day ${ }^{-1}$ & 32.28 & 31.49 & $31.88 \mathrm{~A}$ \\
\hline MO, 125 mg day ${ }^{-1}+\mathrm{VM}, 125 \mathrm{mg} \mathrm{day}^{-1}$ & 32.63 & 31.92 & $32.27 \mathrm{~A}$ \\
\hline MO, 200 mg day ${ }^{-1}+$ VM, 125 mg day ${ }^{-1}$ & 31.91 & 31.21 & $31.56 \mathrm{~A}$ \\
\hline \multirow[t]{2}{*}{ Mean } & $32.27 \mathrm{a}$ & $31.54 \mathrm{a}$ & \\
\hline & \multicolumn{3}{|c|}{ Rectum, ${ }^{\circ} \mathrm{C}$} \\
\hline MO, $200 \mathrm{mg}$ day $^{-1}$ & 38.44 & 38.43 & $38.43 \mathrm{~A}$ \\
\hline MO, $125 \mathrm{mg}$ day $^{-1}+\mathrm{VM}, 125 \mathrm{mg}$ day $^{-1}$ & 38.14 & 38.50 & $38.32 \mathrm{~A}$ \\
\hline MO, 200 mg day ${ }^{-1}+$ VM, 125 mg day ${ }^{-1}$ & 38.71 & 38.66 & $38.68 \mathrm{~A}$ \\
\hline Mean & $38.43 \mathrm{a}$ & $38.53 \mathrm{a}$ & \\
\hline
\end{tabular}

Mean values followed by different lowercase letters, in the same row, are significantly different by F-Test at 5\%.

Mean values followed by different capital letters, in the same column, are significantly different by Tukey's test at $5 \%$.

MO: monensin sodium, VM: virginiamycin.

The metabolic rate of the tissues and the blood flow determine the surface temperature of the animals (Nikkhah et al., 2005), therefore several diseases related to inflammatory processes can consequently alter the blood flow and thus, the temperature of the affected region (Berry, Kennedy, Scott, Kyle, \& Schaefer, 2003). According to Bouzida, Bendada and Maldague (2009), these changes in the skin surface can be verified using infrared thermography (TIV).

The use of TIV has been growing, due to the non-invasiveness of the technique, and it can be used without restraining the animals (Schaefer et al., 2012). Further, it can serve to prevent diseases, by identifying the rise in temperature even before the appearance of clinical signs, allowing thorough observation of the animal (Gloster, Ebert, Gubbins, Bashiruddin, \& Paton, 2011); Redaelli et al., 2014).

Based on the above, it is assumed that MO alone or combined with VM added to the diet for ruminants did not cause vascular changes, capable of altering body surface temperature.

\section{Conclusions}

The combination of monensin sodium with virginiamycin at a dose of $200 \mathrm{mg}+125 \mathrm{mg}$ animal day $^{-1}$ is efficient in the initial period of finishing steers in feedlot, determined by daily weight gain and feed conversion. 


\section{References}

Association of Official Analytical Chemists (1990). Official methods of analysis (15nd ed.). Washington, D.C.: AOAC.

Beacom, S. E., \& Mir, Z. (1985). A comparison of monensin and chlortetracycline in high-concentrate and high-forage diets for implanted and nonimplanted finishing steers and heifers. Canadian Journal of Animal Science, 65(3), 705-715. doi: 10.4141/ cjas85-083

Bergen, W. G., \& Bates, D. B. (1984). Ionophores: their effect on production efficiency and mode of action. Journal of Animal Science, 58(6), 1465-1483. doi: $10.2527 / \mathrm{jas} 1984.5861465 \mathrm{x}$

Berry, R. J., Kennedy, A. D., Scott, S. L., Kyle, B. L., \& Schaefer, A. L. (2003). Daily variation in the udder surface temperature of dairy cows measured by infrared thermography: potential for mastitis detection. Canadian Journal of Animal Science, 83(4), 687-693. doi: 10.4141/A03-012

Bouzida, N., Bendada, A., \& Maldague, X. P. (2009). Visualization of body thermoregulation by infrared imaging. Journal of Thermal Biology, 34(3), 120126. doi: $10.1016 /$ j.jtherbio.2008.11.008

Brown, M. S., \& Millen, D. D. (2009). Protocolos para adaptar bovinos confinados a dietas de alto concentrado. Anais do Simpósio Internacional de Nutrição de Ruminantes, Botucatu, SP, Brasil.

Cocito, C. (1979). Antibiotics of the virginiamycin family inhibitors which contain synergistic compounds. Microbiological Reviews, 43(2), 145-198.

Crooy, P., \& De Neys, R. (1972). Virginiamygin: nomenclature. The Journal of Antibiotics, 25(6), 371-372. doi: 10.7164/antibiotics.25.371

De Somer, P., \& Van Duck, P. (1955). A preliminary report on antibiotic number 899 , a strepto-graminlike substance. Antibiotics \& Chemotherapy, 5(11), 632-639.

DiGiambattista, M., Chinali, G., \& Cocito, C. (1989). The molecular basis of the inhibitory activities of type A and type B synergimycins and related antibiotics on ribosomes. The Journal of Antimicrobial Chemotherapy, 24(4), 485-507. doi: 10.1093/ jac/24.4.485

Duffield, T. F., Merrill, J. K., \& Bagg, R. N. (2012). Meta-analysis of the effects of monensin in beef cattle on feed efficiency, body weight gain, and dry matter intake. Journal of Animal Science, 90(12), 4583-4592. doi: 10.2527/jas.2011-5018
Fereli, F., Branco, A. F., Jobim, C. C., Coneglian, S. M., Granzotto, F., \& Barreto, J. C. (2010). Monensina sódica e Saccharomyces cerevisiae em dietas para bovinos: fermentação ruminal, digestibilidade dos nutrientes e eficiência de síntese microbiana. Revista Brasileira de Zootecnia, 39(1), 183-190. doi: 10. 1590/S1516-35982010000100024

Ferreira, S. F. (2013). Uso de Salinomicina e Virginiamicina na alimentação de bovinos de corte à pasto no verão e no inverno. Tese de doutorado, Universidade Federal de Goiás, Goiânia, GO, Brasil. Recuperado de https://repositorio.bc.ufg.br/tede/ handle/tede/3491

Ferreira, S. F., Guimarães, T. P., Moreira, K. K. G., Alves, V. A., Lemos, B. J. M., \& Souza, F. M. (2013). Caracterização fecal de bovinos. Revista Científica Eletrônica de Medicina Veterinária, 11(20), 1-22.

Food and Agriculture Organization of the United Nations. (2009). Evaluation of certain veterinary drug residues in food: seventieth report of the Joint FAO/WHO Expert Committee on Food Additives. Geneva: FAO.

Fonseca, M. P. (2012). Consumo, digestibilidade aparente e emissão de metano em novilhos F1 Holandês $x$ Gir suplementados com monensina elou virginiamicina. Tese de mestrado, Universidade Federal de Minas Gerais, Minas Gerais, MG, Brasil. Recuperado de https://repositorio.ufmg.br/handle/1843/ VETD8SDNHV

Gibb, D. J., Moustafa, S. M. S., Wiedmeier, R. D., \& McAllister, T. A. (2001). Effect of salinomycin or monensin on performance and feeding behavior of cattle fed wheat-or barley-based diets. Canadian Journal of Animal Science, 81(2), 253-261. doi: 10.4141/A00-057

Gloster, J., Ebert, K., Gubbins, S., Bashiruddin, J., \& Paton, D. J. (2011). Variação normal da temperatura irradiada térmica em bovinos: implicações para a detecção de febre aftosa. BMC Pesquisa Veterinária, 7(1), 73. doi: 10.1186/1746-6148-7-73

Goering, H. K., \& Van Soest, P. J. (1970). Forage fiber analyses (apparatus, reagents, procedures, and some applications) (No. 379). Washington: Agricultural Handbook, D.C.

Guan, H., Wittenberg, K. M., Ominski, K. H., \& Krause, D. O. (2006). Efficacy of ionophores in cattle diets for mitigation of enteric methane. Journal of Animal Science, 84(7), 1896-1906. doi: 10.2527/jas.2005652 
Heker, J. C., Jr., Neumann, M., Ueno, R. K., Falbo, M. K., Galbeiro, S., Souza, A. M., ... \& Askel, E. J. (2018). Effect of monensin sodium associative to virginiamycin and/or essential oils on the performance of feedlot finished steers. Semina: Ciências Agrárias, 39(1), 261-274. doi: 10.5433/1679-0359.2018v39n1p261

Looper, M. L., Stokes, S. R., Waldner, D. N., \& Jordan, E. R. (2001). Managing milk composition: evaluating herd potential. Cooperative Extension Service College of Agriculture and Home Economics. New Mexico State University.

Marques, R. S., Cooke, R. F., Francisco, C. L., \& Bohnert, D. W. (2012). Effeets of twenty-four hour transport or twenty-four hour feed and water deprivation on physiologic and performance responses of feeder cattle. Journal Animal Science, 90(13), 5040-5046. doi: $10.2527 /$ jas2012-5425

Nikkhah, A., Plaizier, J. C., Einarson, M. S., Berry, R. J., Scott, S. L., \& Kennedy, A. D. (2005). Infrared thermography and visual examination of hooves of dairy cows in two stages of lactation. Journal of Dairy Science, 88(8), 2749-2753. doi: 10.3168/jds. S0022-0302(05)72954-4

Nuñez, A. J. C., Caetano, M., Berndt, A., Demarchi, J. J. A. A., Leme, P. R., \& Lanna, D. P. D. (2013). Combined use of ionophore and virginiamycin for finishing Nellore steers fed high concentrate diets. Scientia Agricola, 70(4), 229-236. doi: 10.1590/ S0103-90162013000400002

Oliveira, C. A., \& Millen, D. D. (2014). Survey of the nutritional recommendations and management practices adopted by feedlot cattle nutritionists in Brazil. Animal Feed Science and Technology, 197, 64-75. doi: 10.1016/j.anifeedsci.2014.08.010

Pereira, M. C., Carrara, T. V., Silva, J., Silva, D. P., Watanabe, D. H., Tomaz, L. A., ...\& Millen, D. D. (2015). Effects of different doses of sodium monensin on feeding behaviour, dry matter intake variation and selective consumption of feedlot Nellore cattle. Animal Production Science, 55(2), 170-173. doi: 10.1071/AN14306

Redaelli, V., Bergero, D., Zucca, E., Ferrucci, F., Costa, L. N., Crosta, L., \& Luzi, F. (2014). Use of thermography techniques in equines: principles and applications. Journal of Equine Veterinary Science, 34(3), 345-350. doi: 10.1016/j.jevs.2013.07.007

Rogers, J. A., Branine, M. E., Miller, C. R., Wray, M. I., Bartle, S. J., Preston, R. L., \& Bechtol, D. T. (1995). Effects of dietary virginiamycin on performance and liver abscess incidence in feedlot cattle. Journal of animal science, 73(1), 9-20. doi: 10.2527/1995.7319

Schaefer, A. L., Cook, N. J., Bench, C., Chabot, J. B., Colyn, J., Liu, T., ... Webster, J. R. (2012). The non-invasive and automated detection of bovine respiratory disease onset in receiver calves using infrared thermography. Research in Veterinary Science, 93(2), 928-935. doi: 10.1016/j. rvsc. 2011.09 .021

Silva, S. D. L., Almeida, R. D., Schwahofer, D., Leme, P. R., \& Lanna, D. P. D. (2004). Effects of salinomycin and virginiamycin on performance and carcass traits of feedlot steers. Journal of Animal Science, 82(suppl 1.), 41-42.

Sitta, C. (2011). Aditivos (ionóforos, antibióticos não ionóforos e probióticos) em dietas com altos teores de concentrado para tourinhos da raça Nelore em terminação. Dissertação de mestrado, Universidade de São Paulo, São Paulo, SP, Brasil. Recuperado de https://teses.usp.br/teses/disponiveis/11/11139/tde29112011-150451/en.php

Soares, M., Silva, L., Frazão, O., \& Silva, A. (2015). Aditivos alimentares na nutrição de ruminantes. Revista Eletrônica Nutritime Artigo, 4(12), 41624174.

Squizatti, M. M. (2019). Redução do tempo de adaptação com uso de virginiamicina em dietas para bovinos nelore confinados: padrão de fermentação ruminal e aproveitamento de nutrientes. Dissertação de mestrado, Universidade Estadual Paulista, São Paulo, SP, Brasil. Recuperado de https://repositorio. unesp.br/handle/11449/181850

Statistical Analysis System Institute (1993). SAS/STAT user's Guide: statistics version 6.4 (Vol. 2). Cary, $\mathrm{NC}$ : SAS Inst.

Tedeschi, L. O., Fox, D. G., \& Tylutki, T. P. (2003). Potential environmental benefits of ionophores in ruminant diets. Journal of Environmental Quality, 32(5), 1591-1602. doi: 10.2134/jeq2003.1591

Tedesco, M. J., Gianello, C., Bissani, C. A., Bohnen, H., \& Volkweiss, S. J. (1995). Análises de solo, plantas e outros materiais (Vol. 174). Porto Alegre: UFRGS.

Van Soest, P. J. (1991). Nutritional ecology of the ruminant. Ithaca, NY: Cornell University Press.

Vanderhaeghe, H., \& Parmentier, G. (1960). The structure of factor s of staphylomycin1. Journal of the American Chemical Society, 82(16), 4414-4422. doi: $10.1021 / \mathrm{ja} 01501 \mathrm{a} 070$ 
Vendramini, T. H. A., Takiya, C. S., Silva, T. H., Zanferari, F., Rentas, M. F., Bertoni, J. C., ... Rennó, F. P. (2016). Effects of a blend of essential oils, chitosan or monensin on nutrient intake and digestibility of lactating dairy cows. Animal Feed Science and Technology, 214, 12-21. doi: 10.1016/j. anifeedsci.2016. 01.015

Weiss, W. P., Conrad, H. R., \& Pierre, N. S. (1992). A theoretically-based model for predicting total digestible nutrient values of forages and concentrates. Animal Feed Science and Technology, 39(1-2), 95110. doi: 10.1016/0377-8401(92)90034-4
Zanine, A., Oliveira, J., \& Santos, E. (2006). Importância, uso, mecanismo de ação e retorno econômico dos ionóforos na nutrição de ruminantes. Revista Científica Eletrônica de Medicina Veterinária, 3(6), 45-56.

Zeoula, L. M., Beleze, J. R. F., Geron, L. J. V., Maeda, E. M., Prado, I., \& Paula, M. (2008). Digestibilidade parcial e total de rações com a inclusão de ionóforo ou probiótico para bubalinos e bovinos. Revista Brasileira de Zootecnia, 37(3), 563-571. doi: 10.1590/S1516-35982008000300023 